Article

Aitor Navarro*

\title{
Jurisdiction Not to Tax, Tax Sparing Clauses, and the OECD Minimum Taxation (GloBE) Proposal
}

https://doi.org/10.2478/ntaxj-2021-0004

\begin{abstract}
The OECD Programme of Work on the tax challenges arising from the digitalization of the economy comprises a so-called GloBE (Global Base Erosion) or Pillar Two proposal, consisting of a series of measures aimed at establishing a floor to tax competition by achieving minimum taxation of the income obtained by in-scope multinational enterprises. If such a measure is implemented, developing countries would be severely deprived of the possibility to grant tax incentives to attract FDI and potentially foster economic growth. This contribution emphasizes the importance of the thorough review of their tax policy preferences that developing countries should undertake amidst the rapid adoption of GloBE, which the OECD is pushing to achieve. To illustrate this concern, an examination of implementation issues shows that a deficient enactment of the income inclusion rule proposed in GloBE could paradoxically trigger the applicability of tax sparing clauses aimed at protecting the effectiveness of tax incentives, even when both sets of rules pursue opposing goals.
\end{abstract}

Keywords: Jurisdiction to tax, tax sparing, tax incentives, Pillar Two, GloBE, tax treaties

\section{Introduction}

The adoption of corporate tax incentives by developing countries to attract foreign direct investment is a frequently used policy instrument to foster economic growth. Although it is unclear whether the trade-off in terms of the loss of tax revenue compensates for the alleged benefits, the broad adoption of tax incentives is undisputable. Often, countries cite their sovereignty to justify the exercise of their jurisdiction so as not to tax certain items of income or to tax them a low effective tax rate, to achieve that aim. To protect the effectiveness of these measures at

*Corresponding Author: Aitor Navarro: Carlos III University, Madrid Getafe, Madrid, Spain. Email: aitor.navarro@uc3m.es a cross-border level, several countries introduced tax sparing clauses in their tax treaties. Tax sparing implies granting a notional tax credit at the level of the investor's country of residence. This is a straightforward case of intended double non-taxation that heavily contrasts with the Base Erosion and Profit Shifting (BEPS) project outcomes. Tax sparing clauses aim at enhancing tax competition instead of trying to limit it. These clauses are still present in several treaties worldwide.

Nonetheless, the sequence of events that has taken place after BEPS points towards a severe undermining of a tax incentives-oriented policy. Amid the discussions of a consensus-based solution that addresses the tax challenges of the digital economy, a proposal was made by France and Germany to address the remaining BEPS issues $^{1}$, named the GloBE (global anti-base erosion) proposal or Pillar Two (OECD 2020c). It consists of the adoption of rules inspired by those recently enacted in the latest major tax reform in the US through the Tax Cuts and Jobs Act, namely the Global Intangible Low-Taxed Income (GILTI) and Base Erosion and Anti-Abuse Tax (BEAT) regimes, that aim at ensuring a minimum level of taxation on cross-border income. This proposal entails a significant amendment of the policy objectives pursued by the OECD, as GloBE targets tax competition at a comprehensive level and not only harmful tax competition, as BEPS did. GloBE would entail establishing a floor to tax competition. Adopting lower effective tax rates than those (yet to be) agreed to as a minimum tax would become unsuitable to attract investment. The implications of such a groundbreaking development in international tax law would be unprecedented. Nonetheless, the success of this new approach to tax competition depends not only on a good design of these measures but also on their proper implementation.

Within the context described, the purpose of this contribution is to emphasize the importance of the thorough

1 See the Franco-German declaration at https://www.consil ium.europa.eu/media/37276/fr-de-joint-declaration-on-the-taxationof-digital-companies-final.pdf (all webpages cited were accessed on November 6th, 2020). 
review of their tax policy preferences that developing countries should undertake amidst the rapid adoption of GloBE that the OECD is pushing to achieve. To illustrate this concern, it will be shown that a deficient enactment of the income inclusion rule proposed in GloBE could paradoxically trigger the applicability of tax sparing clauses, even although both sets of regulations pursue opposing goals.

The structure of the paper is as follows. Section 2 explores the rationale of tax sparing as a form of recognition of the jurisdiction not to tax of states willing to attract foreign direct investment through tax incentives, fostering tax competition. Section 3 notes that the BEPS project aims at curtailing tax competition but does not comprehensively address it. Only harmful tax competition and unintended double non-taxation are areas of concern for BEPS. Section 4 explores the rationale of GloBE and its regulatory drive of establishing a floor for tax competition and shows how it addressed this phenomenon comprehensively. Section 5 deals with GloBE-related implementation issues and highlights that the proper achievement of the goals of GloBE requires-among other considerationsa careful review of the interaction between the proposed measures and tax treaties in force containing tax sparing clauses. Section 6 concludes.

\section{Tax Sparing, Jurisdiction Not to Tax, and Sovereignty}

This section deals with tax sparing clauses as a form of recognition of the right of the jurisdiction not to tax belonging to States willing to attract foreign investment through tax incentives. Developing countries often grant corporate income tax incentives allegedly to attract foreign direct investment to ultimately foster economic growth. The impact of these measures depends very much on their design, implementation, and effectiveness, although the overall appropriateness of this policy instrument to achieve that goal is fairly doubtful (Brauner 2013). However, the adoption of tax incentives becomes threatened at a cross-border level when the home country of the investor eliminates double taxation through the credit method. As the credit is calculated by taking into account taxes effectively paid abroad, the amount of taxes saved due to the host country's incentives does not reduce the amount of taxes due in the home country. The country of residence would collect the tax not paid to the source state, thereby hindering the suitability of the tax incentives to attract foreign direct investment. The tax sparing mechanism solves the issue by granting a notional credit for residence-namely, a discount on the taxes due, even if no or lower taxes were paid at sourceand ensures that the investor benefits from the tax waived.

There are two types of tax sparing clauses that would prevent the investor's home state from effectively taxing the income benefiting from an incentive in the host state. On the one hand, contingent tax sparing clauses require the residence state to grant a notional credit equivalent to the tax foregone by the source state by applying a tax incentive scheme, compared with the usual level of taxation had the incentive not existed. For instance, article 23(3) of the tax treaty signed between China and India states:

\begin{abstract}
The tax paid in a Contracting State mentioned in paragraphs 1 and 2 of this article shall be deemed to include the tax which would have been payable but for the legal provisions concerning tax reduction exemption or other tax incentives of the Contracting States for the promotion of economic development. (emphasis added)
\end{abstract}

On the other hand, matching credit clauses ensure a minimum level of credit to be granted in the state of residence, irrespective of the specific taxation level at the state of source, or the granting of tax incentives therein. The higher the spread between the percentage given as a notional credit and the tax rate imposed by the state, the higher the tax benefit for the taxpayer will be. The tax treaty signed between Brazil and Italy determines the following in its article 23(4):

For the deduction mentioned in paragraph 2 of this Article, Brazilian tax shall always be considered as having been paid at the rate of 25 percent of the gross amount:
(a) of the dividends as defined in paragraph 4 of Article 10;
(b) of the interest as defined in paragraph 4 of Article 11, and
(c) of the royalties as defined in paragraph 4 of Article 12 (em- phasis added).

Tax sparing is one of the most controversial topics in the field of tax treaties (Shannon 1992; Hines Jr. 2000; Brauner, 2013), as it is linked to tax incentives and thus to no or lower taxation and refers mainly to policy concerns of developing countries (UN 2017, 471), as well as because of the stark opposition of United States against these clauses. That opposition indeed explains the scarce number of US tax treaties signed with other countries on the American continent (Martin 1998, 445). Moreover, the OECD (1998a) changed its view from endorsing these clauses positively to a significant reluctance in a report named Tax Sparing: A Reconsideration, which remarks on their alleged deficiencies. The existing literature on the subject matter is divided between those that support the use of this policy instrument and those who highlight its shortcomings, both 
from the perspective of developed and developing nations. An analysis of these arguments may be found inter alia in Brooks (2009). In the present contribution, only the policy rationale that justifies the adoption of the clause will be addressed.

Tax sparing clauses have been assessed as an expression of the fiscal sovereignty of the countries demanding their adoption, namely developing countries. According to Schoueri $(2013,121)$, the fact that a country agrees to limit its taxing rights implies the recognition of the jurisdiction to tax of the counterpart. Yet, the opposite, i.e., the decision of a jurisdiction not to tax an item of income, remains controversial. The exemption method grants the recognition of the jurisdiction's right not to tax certain income because it entails that the residence state, in any case, will not tax back the income unless a subject-to-tax clause applies. Nonetheless, in the context of the credit method, when the source jurisdiction decides not to tax a specific item of income or to lower taxes, the residence jurisdiction will effectively tax it, as no or low credit will be granted. The fact that tax sparing provisions prevent the residence state from taxing all or a portion of the income that remained untaxed at source is a relevant expression of the jurisdiction not to tax of the host state and allows it to undertake policy decisions accordingly.

The implementation of tax sparing has been labelled as a quid pro quo in exchange for the lowering of withholding tax rates at source that entail adopting a tax treaty (Martin 1998, 454; Dagan 2000, 994). At the end of the day, tax sparing entails that the residence country also assigns public resources to encourage investment (Liebman 1978, 303; Li 2018, sec.3.2), not only the source country. However, from the perspective of the residence country, the adoption of a tax sparing clause entails a tradeoff by which tax incentives of resident enterprises investing abroad are preserved at the expense of capital export neutrality. Enterprises investing in a country with which a tax treaty containing a tax sparing clause is applicable will obtain a more favorable tax treatment vis-à-vis those investing at home. Indeed, the breach of capital export neutrality is the main argument for the US to reject the adoption of these clauses (Surrey 1958; Tillinghast 1995). Nonetheless, other developed nations accepted the adoption of these clauses in their tax treaties with developing countries, mainly in the 1980-1998 period. Several of these clauses-but not all, as some incorporated a sunset clause that would limit the applicability of tax sparing to a specific period-are still applicable nowadays.

Meanwhile, the views on cross-border non-taxation outcomes through the adoption of tax incentives have changed significantly, especially since the OECD released its 1998 report on harmful tax competition (1998b). However, the outcome of the BEPS project and the new OECD Pillar Two proposal to address remaining BEPS concerns may put an end to the use of tax incentives as a relevant policy instrument. This new approach to tax competition will be dealt with in the following sections.

\section{BEPS and the Fight against Unintended Non-Taxation}

After the 2008 global financial crisis, jurisdictions worldwide needed to improve the collection of taxes, especially with respect to corporate income taxation. Accordingly, the OECD launched an initiative to combat base erosion and profit shifting (BEPS), due to the growing perception that governments lose substantial corporate tax revenue because of planning aimed at shifting profits in ways that erode the tax base (OECD 2013a, 13). In this line of action, it was emphasized that the focus should be on eliminating obstacles to cross-border trade and investment, and limiting the scope for unintended non-taxation (OECD 2013a, 39). As is widely known, the BEPS project achieved significant results. The outcomes expressed in its action plan comprising 15 points took the form of recommendations (OECD 2015e), but the level of adoption of the proposed measures has been significant (Christians 2016; Mason 2020). The most salient example would be the agreement on a minimum standard involving measures designed to counter harmful tax practices (Action 5); the prevention of tax treaty abuse (Action 6); the improvement of transparency through country-by-country reporting (Action 13); and making dispute resolution between jurisdictions more timely, effective, and efficient (Action 14). More than 135 countries have committed to implementing these measures and being subject to a peer-review monitoring process to ensure proper adoption by joining the so-called Inclusive Framework ${ }^{2}$.

Yet, the Action Plan report that kickstarted BEPS stated that no or low taxation is not per se a cause of concern, but it becomes so when it is associated with practices that artificially segregate taxable income from the activities that generate it (OECD 2013b, 10). Hence, the BEPS project did not address non-taxation or undertaxation comprehensively but instead referred to specific

2 See the updated list of the Inclusive Framework members at https://www.oecd.org/tax/beps/inclusive-framework-on-bepscomposition.pdf. 
areas of concern. For instance, the criteria set in Action 6 for a principal purpose test (PPT) rule to be included in tax treaties, as broad as it is, only deny treaty benefits when the tax administration successfully proves that achieving them was "one of the principal purposes of any arrangement or transaction that resulted directly or indirectly in that benefit, unless it is established that granting that benefit in these circumstances would be in accordance with the object and purpose of the relevant provisions" (OECD 2015c). Hence, the clause does not target non-taxation comprehensively. At a different level, the requirements for a regime to be considered harmful under the guidance set on Action 5 refer to the lack of substance, transparency, and coherence. Still, a low or no taxation outcome by itself is not indicative of a harmful measure (OECD 2015b). Moreover, a report prepared by the Platform of Collaboration on Tax (integrated by the IMF, the OECD, the UN and the World Bank) was issued with guidance on options for Low Income Countries' Effective and Efficient Use of Tax Incentives for Investment (PCT 2015).

Although the measures proposed in BEPS have been defined as leading to full taxation outcomes (Mason 2020), the truth is that the action plan set by the OECD to tackle non-taxation outcomes has its limits (Parada 2021). Certain forms of non-taxation or low taxation remained unaddressed and thus permitted, such as the one resulting from tax sparing clauses in tax treaties. One may argue that the underlying tax incentives that tax sparing clauses are linked to are affected by Action 5. Nonetheless, two considerations may relativize such an impact. On the one hand, as stated, the criteria set by Action 5 would not cover all regimes leading to non-taxation. The last update on the peer review results of the Forum for Harmful Tax Practices, dated November $2020^{3}$, shows that several regimes leading to no or low taxation have been declared unharmful due to their compliance with the requirements on substance and transparency. On the other hand, matching credit clauses are not affected by the criteria set out in Action 5. Their applicability does not depend on the reduction of taxes due to a domestic incentive regime.

Nonetheless, that rationale may be superseded due to the implementation of the measures proposed in the new Inclusive Framework's global anti-base erosion proposalalso known as Pillar Two or GloBE. This proposal tackles non- and low taxation comprehensively, regardless of its cause or the jurisdictions' willingness to achieve such a re-

3 See the outcomes of the review process at http://www.oe cd.org/tax/beps/harmful-tax-practices-peer-review-results-on-prefer ential-regimes.pdf. sult. In the next section, the tax policy rationale of Pillar Two will be addressed and will be contrasted with that of tax sparing clauses.

\section{A Comprehensive Proposal against the Non-Taxation of Cross-Border Income. The Rationale of Pillar Two (GloBE) and Its Income Inclusion Rule}

Although the implementation of BEPS measures is still recent and their real effects on investment and tax planning decisions are yet to be ascertained (Hey 2021, 8), the OECD has leveraged its momentum to deal with broader concerns. Once the final reports of the BEPS project were finalized in October 2015, the focus turned to addressing the tax challenges of the digital economy, as the developments of this action point were fairly disappointing at that time. Nonetheless, the discussion on how to grant more taxing rights to market jurisdictions in the context of digitalized business models (OECD 2018) was accompanied with a proposal also to address "remaining BEPS issues" (OECD 2019a, 1; 2020b, 17) beyond digitalization matters. The focus of the so-called Pillar Two would be on strengthening the ability of jurisdictions to tax profits where another jurisdiction with taxing rights applies a low effective rate of tax to those profits, as a systematic solution designed to ensure that all businesses operating internationally pay a minimum level of tax (OECD 2019b). Affected MNEs would be those with a consolidated return of EUR 750 million or more, which is the same threshold used for country-bycountry reporting. In fact, this threshold "is estimated to exclude $85-90 \%$ of MNE groups while still covering MNE groups responsible for approximately $90 \%$ of global corporate revenues" (OECD 2015d, 21). The specific rules to achieve minimum taxation consist of (OECD 2020c, 15-17): (1) a so-called "income inclusion rule" that would tax the income of a foreign branch or a controlled entity if that income was subject to tax at an effective rate that is below a minimum rate, (2) an "undertaxed payments rule" that would operate by way of a denial of a deduction or imposition of source-based taxation (including withholding tax) for a payment to a related party if it were not subject to tax at or above a minimum rate, (3) a switch-over rule to be introduced into tax treaties that would permit a residence jurisdiction to switch from an exemption to a credit method where the profits attributable to a permanent es- 
tablishment (PE) or derived from real estate (which is not part of a PE) are subject to an effective rate below the minimum rate, and (4) a subject-to-tax rule that would subject payments to withholding or other taxes at source where the payment is not subject to tax at a minimum rate.

Englisch and Becker (2019, 488-490) describe the rationale of Pillar Two-or at least, its desirable effects-as entailing (1) improvement of the efficiency in the international allocation of capital, as firms would have an incentive to focus on maximizing their before-tax return instead of their after-tax return; (2) a reduction of the motivation to shift profits to low-tax jurisdictions, as gains derived from tax savings will not be as significant as they currently are; and (3) the mitigation of tax competition, as low-tax countries will have an incentive to increase their tax rates to approach the minimum rate because, otherwise, another jurisdiction will tax the amounts of income that remained untaxed or taxed very low until now. Undoubtedly, the achievement of these points constitutes a significant breakthrough from the rationale of the BEPS project, as the Pillar Two proposal would limit tax competition comprehensively. This means that tax competition resulting in lower effective tax rates than the minimum tax will be curtailed, irrespective of whether the low taxation result derives from abusive practices, aggressive tax planning, or legitimate economic activities. In a way, it serves to put an end to the discussion of the scope of these concepts. That is, fine-tuned classifications of abuse, avoidance, or legitimate planning would become irrelevant below this minimum level of taxation. A sound rationale to do so could be to prevent tax competition by reducing tax rates or through tax measures designed to attract investment that comply with the criteria drawn in BEPS Action 5 (Gadžo and Jozipović 2020, 442).

The differing reach of the measures proposed in the BEPS project and the Pillar Two proposal can be illustrated by comparing CFC rules-the adoption of which was recommended in Action 3 of the BEPS plan (OECD 2015a)-and the income inclusion rule of Pillar Two. Both attribute income obtained by a controlled foreign corporation to its parent company, thus granting the residence state of this controlling entity the right to tax it. This is the reason that in the draft documents referred to in Pillar Two, it is stated that the income inclusion rule draws on the design of CFC rules (OECD 2020a, 28; OECD 2020c, 15). Nonetheless, the differences between the two sets of rules are remarkable. (1) While the income inclusion rule is designed to attribute the income obtained, from a private/accounting law perspective, by the controlled entity to its parent company, CFC rules can also be structured differently: in accordance with a deemed dividend approach (sharehold- ers are deemed to have received a dividend distribution, which has not actually taken place) or a notional sum approach providing an increase of the taxable base equal to the fair value of the participation in that subsidiary (Rust 2008, 493 and Canè 2017, 528-529). (2) In the framework of the income inclusion rule, the calculation of the income to be attributed relies on generally accepted accounting principles (Dourado 2020, 155) such as the International Financial Reporting Standards (IFRS), adjusted and blended on a per-country basis (OECD 2020c, 72). On the other hand, the income captured by CFC rules is usually calculated according to the rules for determining the taxable base of the parent company's residence country. (3) In the case of CFC rules, the tax treatment of the income attributed to the controlling entity usually bears the same tax burden as other equivalent income. It would certainly not depend on the difference between the effective tax rate levied abroad and a consensus-based minimum tax rate, as happens with the income inclusion rule of Pillar Two (Hey 2021, 11-12). (4) CFC rules are often drafted carefully to apply only to controlled entities located in low-tax jurisdictions that earn passive, tainted income (Blum 2018, 305; Arnold 2019, 633). In fact, countries try to balance the protection of the domestic tax base with the noninterference in the undertaking of legitimate business activities abroad, as an attempt to preserve international competitiveness. The income inclusion rule would comprehensively tax income that was subject to an effective tax rate below a figure yet to be agreed on by the Inclusive Framework (OECD 2020c, 15).

To better understand the rationale of Pillar Two, it is essential to highlight its regulatory function (Gadžo and Jozipović, 2020), as its primary aim is to put a floor on tax competition. When input costs, infrastructure, and institutional factors are equivalent, MNEs are highly responsive to effective tax rates (Altshuler and Grubert 2005). As a result, countries engage in tax competition to attract investment, as exemplified by tax sparing clauses adopted by developing countries in their tax treaty network. Pillar Two aims to establish limits to this beggar-thy-neighbor approach to attracting investment at the expense of tax collection (Avi-Yonah 2000; Christians 2013). The Pillar Two proposal would discourage the adoption of measures leading to an effective tax rate below the agreed minimum, as the aim of attracting foreign investment would become nullified. The regulatory function of Pillar Two is clearly reflected in the fact that the specific measures would only display effects if cross-border income is taxed at a rate below the agreed upon minimum rate. Indeed, the primary taxing right lies on the other involved jurisdiction(s). Otherwise, the delineation of a sovereign coun- 
try's jurisdiction to tax by reference to the effective tax rate adopted in other jurisdictions seems quite absurd. Once implemented, the ideal outcome of Pillar Two is to become inapplicable, a scenario in which all jurisdictions levy the agreed upon minimum effective tax rate on all crossborder income. Only then would the real aim of Pillar Two be achieved, i.e., the mitigation of tax competition-yet not its complete elimination, as the spread between the minimum effective tax rate and the effective tax rate adopted by each country allows for tax competition. Therefore, the right not to tax in a given jurisdiction, as a form of tax sovereignty, is sacrificed at the expense of the ability of states to tax income cross-border effectively.

Ideally, as stated by Faulhaber $(2017,357)$, a minimum tax shifts competition from effective rates to anything else, including infrastructure, rate of return, legal protection, or other elements on which an investor company might base its investment decisions. Nonetheless, in this endeavor, not all states are equally positioned. Indeed, developing countries have traditionally used tax incentives to attract investment to compensate the investor for shortcomings such as worse infrastructure, less political stability, corruption, etc. As Schoueri puts it $(2013,119)$, the equalization of tax rates would operate as a mechanism to convince investors not to invest in developing countries but instead focus their investment on developed countries, at least from a tax perspective. Under the same level of taxes, investors will prefer to invest in an environment where infrastructure corresponds to the level of taxation the investor is paying. It would be naïve to ignore such a downside of the adoption of Pillar Two. Moreover, suppose corporate tax incentives are no longer possible. In that case, there could be a shift to incentives on indirect taxes, social security, or subsidies, in order to attract foreign investment. This shift would be equally distortive of the capacity of the country to obtain revenue for implementing public policies.

Moreover, one may wonder about the policy rationale of adopting a proposal that outdates a significant part of the work undertaken so far in the context of the BEPS plan. Several stakeholders have raised this point in the public consultation organized to gather feedback on the Pillar Two proposals (Larking 2020). Most probably, the answer has to do more with political science or game theory dilemmas (Rosenzweig 2012) than with a normative approach. It turned out that the political momentum generated by the BEPS project, the broad consensus on the adoption of the minimum standard, and the leverage for the Inclusive Framework raised a unique opportunity to go beyond the fight against profit shifting or the taxation of digitalized businesses. Additionally, the fact that the
United States has unilaterally adopted GILTI serves as a catalyzer for multilateral cooperation on adopting similar rules, just as FATCA did in the realm of information exchange (Beller 2019). Pillar Two may also be addressed as entailing a clear statement by certain jurisdictions-mainly developed ones-of their willingness to undertake a significant expansion of their jurisdiction to tax at the expense of the right of other countries not to tax. A consensus-based adoption is not necessary from a practical standpoint, even if developing countries express sovereignty concerns. Besides, the sovereignty argument that is often mentioned to justify the adoption of tax incentives may also be put forward by developed states to defend such an expansion of taxing rights. After all, their revenue collection possibilities are affected by the tax expenditures granted by others (Ring 2009, 592). As Devereux et al. $(2020,13)$ state, when "countries compete they impose costs on other countries, either by shifting investment away from other countries or by forcing them to reduce their tax rates."

That said, it remains unclear whether the proposal is the best option for all concerned parties. This is why every country involved (but especially developing countries) should undertake a thorough examination of whether the measures are compatible with their interests in the long run. Preferably, it should be done so with economic analyses that could help to predict the consequences of a new scenario in which tax competition would be significantly limited. Nonetheless, pressure by the OECD to achieve a fast-delivered agreement may curtail a reasoned adoption (Christians 2019, 500). A salient example of the OECD's rising demands in this regard is found in specific passages of the draft documents of Pillar Two, such as the statement that Pillar Two will "effectively shield developing countries from the pressure to offer inefficient tax incentives." Such a general categorization of tax incentives as inefficient measures and the insidious blaming of developing countries with respect to the issues Pillar Two aims to resolve has already been labeled as overtly paternalistic (Arnold 2019, 647) and could very well fit into the notion of international fiscal imperialism that Rocha (2014 and 2017) and Magalhães (2018) describe. It is still to be seen whether members of the Inclusive Framework will raise their voices against such an approach to the subject matter.

At a more specific level, the adequate implementation of the proposals enshrined in Pillar Two will be a crucial aspect to determine their viability and compatibility vis-àvis tax treaties and conflicting measures such as tax sparing clauses. In this regard, it is evident that Pillar Two and tax sparing pursue opposite aims. A rational implementation of the former should lead to the disappearance of the 
latter. Yet, several issues arise in this regard, as shown in the next section.

\section{Implementation Issues of the Income Inclusion Rule and Its Interaction with Tax Treaties Containing a Tax Sparing Clause}

As with any other tax measure, the adequate implementation of the measures proposed in Pillar Two is critical to achieving its declared policy goals. Nonetheless, the exhaustiveness of the configuration of the scope of the GloBE rules, its calculation, and its enforcement remains in stark contrast with the utterly poor treatment of implementation issues, especially regarding the compatibility with double tax treaties (OECD 2020c, 171-175). What seems clear is that a unanimous and uniform implementation is very unlikely to happen. Most probably, the OECD will face an asymmetric scenario, in which certain countries will indeed adopt the measures agreed upon; perhaps some will opt for a partial implementation, and others will plainly refuse them. This may entail compatibility issues with existing tax treaties and, more specifically, with tax sparing clauses, which will be reviewed in this section.

There are various alternatives for the specific implementation of the Pillar Two measures, e.g., (1) the adoption of a new multilateral convention, including all relevant provisions to properly enforce the proposed rules; (2) the adoption of a multilateral convention that sets the framework for a domestic implementation in a uniform and coherent fashion; (3) the modification of the existing Multilateral Convention to implement tax treaty-related measures to prevent base erosion and profit shifting (MLI), through the procedure indicated in its article 33; (4) the issuance of recommendations for a uniform adoption of measures in the domestic law accompanied by a broader adoption of the saving clause present in article 11 of the MLI; or (5) the issuance of recommendations for a uniform adoption of measures in the level of domestic law, with no further modifications to the existing rules at a treaty level, among other possible combinations.

The adoption of the GloBE measures through a multilateral agreement would be the best choice to avoid potential conflicts of rules, as it would entail an express commitment by all parties involved that would ideally result from a process of thoughtfulness in which all the advantages and disadvantages that entails putting a floor to tax competition are weighted. Nonetheless, the diverging in- terests at stake are a significant impediment to achieving this path. The precedent of the MLI and its peculiar "swiss cheese" design with multiple opt-out clauses and reservation possibilities bodes ill for success in this endeavor (García Antón 2019, 462). Moreover, the proposed measures-mainly the income inclusion rule and the limitation on the deductibility of cross-border paymentsclearly point to an adoption by a few economically relevant countries that would force the rest of the world to modify their effective tax rate (Herzfeld 2019). The United States already has similar rules in place, and the European Union could adopt them through a directive that, despite implying specific issues described inter alia by Englisch and Becker (2019) and Nogueira (2020), would supersede tax treaties due to the principle of the supremacy of EU law over other international agreements. Other countries with a significant presence of MNE headquarters, such as the United Kingdom, Japan, Canada, or Australia, could adopt the proposed measures through domestic law.

In any case, an implementation in domestic law should be accompanied by measures to overcome incompatibility issues. A feasible option could be the wide adoption of the saving clause enshrined in article 11 MLI and art.1.3 of the 2017 OECD and UN Model Tax Conventions ${ }^{4}$. This provision has been a traditional component of the US tax treaty policy to safeguard the taxation of residents and nationals from any possible interference by tax treaties in force (Kofler 2016, 576-9). It also helps to secure the applicability of domestic anti-abuse legislation focused on the taxation of residents, such as the CFC rules, which a tax treaty will not limit. Yet, it seems that the majority of countries that have contemplated the possibility of adopting the clause are not concerned about these compatibility issues, as the saving clause included in the MLI was subject to a reservation by the majority of the signatory states ${ }^{5}$.

4 The clause reads as follows: This Convention shall not affect the taxation, by a Contracting State, of its residents except with respect to the benefits granted under paragraph 3 of Article 7, paragraph 2 of Article 9 and Articles 19, 20, 23 [A] [B], 24, 25 and 28.

5 According to the OECD's MLI matching database, available at https://www.oecd.org/tax/treaties/mli-matching-database.htm, the countries that have reserved the applicability of the saving clause envisaged in article 11 MLI are Albania, Austria, Barbados, Belize, Bosnia and Herzegovina, Bulgaria, Burkina Faso, Cameroon, Canada, Costa Rica, Côte d'Ivoire, Croatia, Curaçao, Cyprus, Czech Republic, Egypt, Estonia, Finland, France, Georgia, Germany, Greece, Guernsey, Hong Kong (China), Hungary, Iceland, Ireland, the Isle of Man, Israel, Italy, Japan, Jersey, Jordan, Kazakhstan, Korea, Kuwait, Latvia, Liechtenstein, Lithuania, Luxembourg, Malaysia, Malta, Mauritius, Monaco, Morocco, the Netherlands, Nigeria, North Macedonia, Oman, Pakistan, Panama, Papua New Guinea, Peru, Qatar, San 
It is still unclear whether the adoption of the income inclusion rule in Pillar Two will reverse actual scarce implementation. Thus, it is crucial to address what would happen if the income inclusion rule is adopted in domestic law with no further changes to tax treaties. This implementation option seems to be the one preferred for the income inclusion rule and the undertaxed payments rule. The OECD considers that these rules do not pose conflicts with double tax treaties (OECD 2020c, 171). In such a context, the discussion of the compatibility of CFC rules and tax treaties attains the highest relevance, as it may be extrapolated to ascertain whether tax treaties may pose any restriction on the income inclusion rule of Pillar Two. If an incompatibility is found, those jurisdictions not adopting it and the taxpayers involved could claim that a breach of the tax treaty and thus a treaty override exists.

\subsection{The Evolving Stance of the OECD As Regards the Compatibility of CFC Rules and Tax Treaties}

The OECD has significantly changed its position on this subject matter, as Arnold (2019, 640-641) explains. Until 1992, the OECD Commentaries did not elaborate on the relationship between CFC rules and tax treaties. Instead, they only included a short reference to the need to have a clause authorizing the applicability of domestic antiabuse measures in tax treaty scenarios by those jurisdictions concerned with this phenomenon, as stated in paragraph 7 of the 1977 Commentary on article 1 (OECD 1977). In 1992, the commentaries were modified (OECD 1992) to incorporate the results of the OECD Reports on the base and conduit companies (OECD 1987, 70). Paragraph 23 of the commentary on Article 1 was included in the commentaries, stating that "such measures are part of the basic domestic rules set by national tax law for determining which facts give rise to tax liability. These rules are not addressed in tax treaties and are therefore not affected by them.” In 2003 (OECD 2003, 64), this paragraph was altered again to explicitly endorse CFC rules as a legitimate instrument to protect the domestic tax base. The enforcement of CFCs would not be restricted by tax treaties, despite doubts raised on the effect of treaty provisions equivalent to articles 7(1) and 10.5 of theModel Tax Convention that state (extract):

Marino, Saudi Arabia, Serbia, the Seychelles, Singapore, Slovenia, South Africa, Spain, Sweden, Switzerland, Tunisia, Turkey, Ukraine, the United Arab Emirates, and Uruguay.
Article 7(1) The profits of an enterprise of a Contracting State shall be taxable only in that State unless the enterprise carries on business in the other Contracting State through a permanent establishment situated therein....

Article 10(5) Where a company which is a resident of a Contracting State derives profits or income from the other Contracting State, that other State may not ... subject the company's undistributed profits to a tax on the company's undistributed profits, even if the dividends paid or the undistributed profits consist wholly or partly of profits or income arising in such other State.

Article 7(1) could be read as preventing the state of the controlling entity from taxing the profits obtained by the foreign-controlled entity, because the profits of the controlled entity shall be taxable only in its residence state unless the controlled entity has a permanent establishment in the residence state of the controlling entity. On the other hand, article 10(5) would limit the residence state's power to tax the controlling entity on profits obtained by the controlled entity that remain undistributed.

To overcome such a restrictive approach, the 2003 Commentary on article 1 refers to argumentation posed in paragraph 10.1 of the Commentary on article 7(1) and paragraph 37 of the Commentary on article 10(5) to reinforce the expressed position on the compatibility of CFC clauses with tax treaties. Nonetheless, these paragraphs do not provide a satisfactory solution to the issue, as they do not contain arguments but merely self-affirmative statements that slightly fit the wording of the said provisions:

Article 7, paragraph 10.1: The purpose of paragraph 1 is to provide limits to the right of one Contracting State to tax the business profits of enterprises that are residents of the other Contracting State. The paragraph does not limit the right of a Contracting State to tax its own residents under the provisions specified for controlled foreign companies found in its domestic law even though such tax imposed on these residents may be computed by reference to the part of the profits of an enterprise that is resident of the other Contracting State that is attributable to these residents' participation in that enterprise. Tax so levied by a State on its own residents does not reduce the profits of the enterprise of the other State and may not, therefore, be said to have been levied on such profits (see also paragraph 23 of the Commentary on Article 1 and paragraphs 37 to 39 of the Commentary on Article 10).

Article 10, paragraph 37: It might be argued that where the taxpayer's country of residence, pursuant to its controlled foreign companies' legislation or other rules with similar effect, seeks to tax profits which have not been distributed, it is acting contrary to the provisions of paragraph 5. However, it should be noted that the paragraph is confined to taxation at source and thus has no bearing on the taxation at residence under such legislation or rules. In addition, the paragraph concerns only the taxation of the company and not that of the shareholder. 
Despite the lack of suitable arguments to support the compatibility of CFC rules and tax treaties (Martín Jiménez 2003), the OECD doubled the stakes when affirming in paragraph 23 of the Commentary on Article 1 that "Whilst some countries have felt it useful to expressly clarify, in their conventions, that controlled foreign companies' legislation did not conflict with the Convention, such clarification is not necessary." This statement is particularly relevant for discussing the compatibility of tax treaties and the income inclusion rule of Pillar Two, as it neglects the very existence of the issue. Moreover, the 2017 OECD Model Tax Convention, which includes among its provisions a saving clause that would solve the compatibility issue, reiterates once again this idea in paragraph 81 of the Commentary on article 1 (OECD 2017, 78) by stating that CFC rules are in line with tax treaties even if a treaty does not contain such a clause. Such a proclamation is even more surprising because it implies that the saving clause has no relevance whatsoever on the compatibility issue, which makes one wonder why the saving clause was included in the Model in the first place.

The flawed reasoning offered by the OECD clearly indicates that the issue is far from clear. This discussion has been addressed by a significant number of scholars and case law with differing views, as the compilation of references made by Kuzniacki (2015, 760), Kofler $(2016,583)$, or Hattingh (2020, sec.3.2.3) shows. Probably the most convincing argument to support the compatibility of CFC rules, as well as the income inclusion rule of Pillar Two, and tax treaties is the fact that tax treaties do not pose limits on domestic income attribution rules, endorsed inter alia by Lang $(2003,54)$, Wheeler $(2012,23)$, and Canè (2017, 534). If article 7(1) is read with this idea in mind, from the perspective of the controlling entity, "the profits of an enterprise of a Contracting State" include any profits defined as such by the domestic rules of the residence state of the controlling entity, as well as the ones resulting from the application of CFC rules. That said, it must be stated that implementation through domestic law of CFC-like measures such as the income inclusion rule of Pillar Two generates incompatibility concerns that could be easily overcome by adopting a saving clause.

\subsection{The Income Inclusion Rule of GloBE May Trigger Tax Sparing Clauses}

Nevertheless, the implementation of Pillar Two in domestic law, even if accompanied by adopting the saving clause through the MLI, does not preclude the application of tax sparing clauses embedded in tax treaties because the sav- ing clause explicitly excludes article 23 from its scope. Therefore, the implementation of the income inclusion rule of Pillar Two could paradoxically trigger the applicability of tax sparing provisions, even though the fact that their purported goals are mutually exclusive. The majority of the tax credit clauses that are included in tax treaties in force are based on the modeled clauses of the OECD or the UN Model Conventions in their pre-2017 version, which read as follows in article 23B(1):

Where a resident of a Contracting State derives income or owns capital which, in accordance with the provisions of this Convention, may be taxed in the other Contracting State, the firstmentioned State shall allow:

(a) as a deduction from the tax on the income of that resident, an amount equal to the income tax paid in that other State....

Such deduction in either case shall not, however, exceed that part of the income tax or capital tax, as computed before the deduction is given, which is attributable, as the case may be, to the income or the capital which may be taxed in that other State. (emphasis added)

Again, the OECD Commentary experimented with a significant change in its approach to the issue. Until 2017, the OECD Commentaries admitted the granting of a tax credit at the level of the state of residence of the controlling entity for taxes on income derived by a controlled foreign entity. Specifically, the reasoning of the OECD Partnership Report was considered as useful to ascertain an adequate interpretation of the said provision (Rust 2008, 495). In the end, the outcome of CFC rules based on an income attribution approach-as well as the income inclusion rule of Pillar Two-resembles what happens when a jurisdiction attributes income obtained by a foreign entity considered tax transparent but as taxable in its country of residence. In this regard, paragraph 69(2) of the 2000-2014 OECD Commentaries on article 23 encapsulates the content of the Partnership Report (OECD 1999, 49-50) when stating that (emphasis added):

... To the extent that the State of residence flows through the income of the partnership to the partner for the purpose of taxing him, it must adopt a coherent approach and flow through to the partner the tax paid by the partnership for the purposes of eliminating double taxation arising from its taxation of the partner....

This statement is clearly in line with the wording of the pre2017 version of article $23 \mathrm{~B}(1)$ : a resident of a contracting state-namely, the controlling entity-would derive income due to a CFC rule or the proposed income inclusion rule of Pillar Two that may also be taxed in the other contracting State, namely, the State of residence of the controlled foreign corporation, due to article 7(1). Indeed, when attributing the income of a controlled foreign entity to its parent 
through a CFC rule or the proposed Pillar Two income inclusion rule, the residence state of the controlling entity, is taxing business profits that the other contracting state also may tax. Hence, taxation takes place "in accordance with the provisions of (the) Convention," as article $23 \mathrm{~B}(1)$ requires.

The commented aspects are fairly relevant for tax sparing clauses. The attribution of income caused by a CFC rule or the income inclusion rule of Pillar Two would automatically entail the existence of notional credits that do not require the payment of actual taxes by the controlled entity. For instance, the DTC signed by Norway and Brazil (1980) states the following in its article 24 (emphasis added):

3. Where a resident of Norway derives income which, in accordance with the provisions of paragraph 2 of Article 10, Article 11, Article 12, paragraph 3 of Article 13, Article 14, Article 22 and items 5 and 11 of the Protocol may be taxed in Brazil, Norway shall allow as a deduction from the tax on the income of that person an amount equal to the tax paid in Brazil.

4. For the deduction indicated in paragraph 3, Brazilian tax on dividends, interest and royalties shall always be considered as having been paid at a rate of $25 \%$.

If Norway adopts an income inclusion rule that attributes, and taxes accordingly, the income generated by a controlled entity resident in Brazil of the controlling entity resident in Norway, then "a resident of Norway derives income ... which may be taxed in Brazil," and thus "Norway shall allow as a deduction" the tax that is "considered as having been paid at a rate of $25 \%$ " in the case of dividends, interest and royalties. Hence, the taxpayer will be entitled to a tax credit of $25 \%$ of the amount of this income, irrespective of the top-up tax Norway may apply following the regulations of the income inclusion rule. This example helps to illustrate how an income inclusion rule would trigger the applicability of tax sparing rules with respect to those tax treaties for which the credit method rule is drafted following the pattern of the above-copied pre-2017 article 23B.

Perhaps as an anticipation of the issues that would be derived from the widespread adoption of comprehensive CFC rules, such as the income inclusion of Pillar Two, the OECD decided in 2017 to change the wording of both the Model Tax Convention and the Commentaries of Article 23. The change was specifically to establish that the methods to eliminate double taxation at residence will not apply if taxation in the other state happens solely because the income is also derived by a resident of that state. Article 23B(1) of the 2017 OECD and UN Model Tax Conventions states the following (the newly added sentence is emphasized):
Where a resident of a Contracting State derives income or owns capital which may be taxed in the other Contracting State in accordance with the provisions of this Convention (except to the extent that these provisions allow taxation by that other State solely because the income is also income derived by a resident of that State or because the capital is also capital owned by a resident of that State), the first mentioned State shall allow:

(a) as a deduction from the tax on the income of that resident, an amount equal to the income tax paid in that other State....

The above-copied paragraph 69.2, containing the findings of the Partnership Report, was also modified and reads as follows in its new version (emphasis added on the new wording):

... To the extent that the State of residence of the partner flows through the income of the partnership to the partner for the purpose of taxing that partner, it must adopt a coherent approach and flow through to the partner the tax paid by the partnership (but only to the extent that such tax is paid in accordance with the provisions of the Convention that allow source taxation) for the purposes of eliminating double taxation arising from its taxation of the partner...

Moreover, paragraph 11.1 of the 2017 OECD Commentaries on article 23 states (emphasis added on the new wording):

In some cases, the same income or capital may be taxed by each Contracting State as income or capital of one of its residents.... The phrase "(except to the extent that these provisions allow taxation by that other State solely because the income is also income derived by a resident of that State or because the capital is also capital owned by a resident of that State)" clarifies that in such cases, both States are not reciprocally obliged to provide relief for each other's tax levied exclusively on the basis of the residence of the taxpayer... . Whilst this result would logically follow from the wording of Articles $23 \mathrm{~A}$ and $23 \mathrm{~B}$ even in the absence of that phrase, the addition of the phrase removes any doubt in this respect.

If one applies this new line of interpretation to the example mentioned above, Norway would not be obliged to grant a notional credit derived from the matching credit clause of its tax treaty signed with Brazil, as article 23(3) of that treaty, the tax credit provision, would not apply. The income is taxed in Brazil not as the source, but as the residence country of the controlled entity. Hence, the outcome the OECD proposes in the 2017 version of the Commentaries is opposed to the solution provided by its previous versions and the OECD Partnership Report. The fact that such a radical change in the interpretation is assessed as a mere clarification that "would logically follow from the wording of Articles 23A and 23B even in the absence of that phrase" without any apparent reason is fairly unsatisfactory. What the OECD considers logical in the 2017 version of the Commentaries is exactly the opposite of what was 
considered logical in the previous versions of the Commentaries. There is no apparent reason to justify such a change in the interpretation of the provision. In fact, this change was proposed in the final report of Action 6 without any further justification, as it was "put forward during the last stages of [the] work" (OECD 2015c, 88).

Moreover, this change obviates the content of the provisions tailored after article 23B.1 of the OECD Model Tax Conventions previous to 2017, as it entails a restriction in their scope that by no means can be anchored to their wording, as article 31.1 of the Vienna Convention in the Law of Treaties (VCLT) requires (Sinclair 1984, 115). Such an intended "policy through interpretation" approach is fairly dangerous when it goes beyond the limits of interpretation. It goes beyond the terms of the provision and thus constitutes an effective breach of both the Pacta Sunt Ser$v a n d a$ and the good faith principle enshrined in the VCLT and part of the international customary law. This breach becomes more evident when such a drastic change in the position is not accompanied by thorough reasoning and an effort to try to sustain the validity of the new approach, as happens in this case. As stated elsewhere, the role that nonbinding interpretation documents, such as the OECD Commentaries, must play in the interpretative process is to provide sound arguments that assist the interpreter in choosing the best interpretative outcome. The prevalence of one interpretation over others should be grounded in the strength of the arguments posed therein and not on the intended superiority of a specific version, whether older or newer, of this document alone (Navarro 2020). The same argument may be helpful to refute the rejection of the reasoning posed in the above-copied paragraph 69.2 of the 2000-2014 OECD Commentaries because of "clear expert evidence that the Commentary was intentionally limited to partnerships" (Arnold 2018, 431). To make the interpretation of article 23B dependent on the pretended scope of a nonbinding interpretation document is fairly misguided, especially when the wording of the interpreted provision and the analyzed issue is the same, i.e., the overlap on the taxation of the same income by two states due to their differing income attribution rules. The only requirement for article 23B to be applicable refers to the obtention of income that the other Contracting State may also tax, which is the case for $\mathrm{CFC}$ rules and the income inclusion proposal of Pillar Two.

A view of the methods to relieve double taxation at residence as only endorsing juridical double taxation, not economic double taxation, expressed in the OECD Commentaries (OECD 2017, 376) is equally unconvincing. First, the vast majority of tax treaties currently in force do not limit the scope of the methods to source-residence con- flicts, as does the new wording introduced in article 23B of the 2017 OECD and UN Model Tax Conventions. In this respect, it is hard to find treaties in which it is explicitly stated that the aim is to relieve only juridical double taxation (Oguttu 2009). The elimination of double taxation is one of the main aims of tax treaties. However, these instruments do not endorse all forms of double taxation, only those addressed explicitly in their wording. With this idea in mind, it seems pretty unreasonable to support a restriction in the scope of article 23B that entails ignoring a form of double taxation that fits in its wording (Parada 2019, 39). Moreover, in the case of tax treaties containing a tax sparing clause, one does not even need to focus on the existence of economic double taxation. The aim of tax sparing is to prevent the taxation at residence of income that was not taxed at source in order to preserve the jurisdiction not to tax the income by the source (developing) jurisdiction. Hence, even from a purposive viewpoint, tax treaties containing tax sparing clauses demand the application of article 23B, including the deemed credit, to scenarios in which the residence state attributes income to the parent company.

The discussion is not merely raised as a concern for the future but has also been addressed before Courts of law. Similar queries were analyzed in the New Zealand Lin case $^{6}$, commented by Arnold (2018), Holmes (2018), and Elliffe (2019). Mrs. Lin, a New Zealand resident, owned a 30\% participation in two Bermudan companies, which owned interests in five Chinese resident companies that were considered controlled foreign companies under applicable New Zealand CFC legislation. These companies benefited from Chinese tax incentives that would qualify for a deemed credit under the tax sparing clause contained in the China-New Zealand tax treaty. This tax sparing clause lists the specific incentives that would qualify for a deemed tax credit. The applicability of the deemed credit resulting from this clause was denied by the tax authorities, on the grounds that the credit rule of the ChinaNew Zealand tax treaty was not applicable, as "no Chinese tax has been paid by Ms. Lin on attributed CFC income which is a separate stream of income from the income derived by the Chinese Companies as a matter of legal form". The High Court decided otherwise, basing its position partially on reviewing the aforementioned arguments posed in the OECD partnership report. The New Zealand's Court of Appeal reversed the decision by adopting a narrower

\footnotetext{
6 Lin v. Commissioner of Inland Revenue [2017] NZHC 969. Lin v. Commissioner of Inland Revenue [2018] NZCA 38. Lin v. Commissioner of Inland Revenue [2018] NZSC 54.
} 
view on the scope of the credit article. It dismissed the argumentation simply because it considered that "it does not assist where the text is plain" (paragraph 32). Although the decision of the New Zealand Court of Appeal goes against the argumentation in this contribution, for the wrong reasons in the opinion of the author,, it serves to illustrate that the issue has already been raised. A faulty implementation of the income inclusion rule of Pillar Two may exacerbate these issues.

\subsection{The Key Takeaway from the Interaction between Tax Sparing and the Income Inclusion Rule of GloBE}

The key takeaway of the discussion is that tax sparing clauses may continue to be applicable in scenarios in which the income inclusion rule is implemented through domestic law, even if the adoption is accompanied by a massive embrace of the saving clause enshrined in the MLI. This fact would generate significant tension between the two sets of rules, as they pursue opposing aims. A solution based on a subtle change to the Commentaries impeding the application of tax sparing clauses must be denounced. It is contrary to the legitimate expectations of the countries that impose their adoption in tax treaties, and thus contrary to the Pacta Sunt Servanda principle, which is one of the cornerstones of International Public Law. Other unilateral solutions, such as the adoption of domestic legal measures impeding the applicability of tax sparing clauses in countries that allow treaty override, including their override through a Directive in the context of the European Union, should also be regarded as unsatisfactory due to the same reasons. These unsatisfactory solutions obviate the tension between the policy rationale of Pillar Two and tax sparing clauses and exacerbate tensions that could lead to legal disputes. The likelihood of conflicts in the interpretation and application of these provisions is even more significant if one considers the fact that the countries that are more prone to impulse the Pillar Two measures are those developed nations that were obligated to grant notional credits through several tax sparing agreements with developing countries. These countries are where these conflicts will have to be addressed by taxpayers, tax authorities, and the judiciary.

All these undesirable outcomes could be solved by a proper agreement on the implementation of rules superseding tax sparing clauses by the parties involved through the adoption of measures that properly address these issues. A consent-based approach would enhance legitimacy in the implementation of Pillar Two overall and would reduce the normative frictions described. Nonetheless, so far, this desirable involvement of the less developed countries in the process has been rather unsatisfactory. As Brauner stresses (2020, 272), "the haste of the BEPS and post-BEPS work on the taxation of the digital economy has led to ineffective participation of the less powerful economies in the process, beginning with their non-participation in the setting of the agenda, the tight schedule and the focus on the technical, so-called pragmatic solution that masked the potentially undesirable impact of the project's outcome on such countries." The combination of the lack of participation and the extremely rapid pace of the project may lead to disappointing outcomes from the standpoint of inclusiveness in the decision-making process for international tax standards, especially in what concerns the proper implementation of the proposed measures.

\section{Conclusions}

The purpose of this contribution was to emphasize the importance of the thorough review developing countries should undertake on their tax policy preferences amidst the rapid adoption of GloBE that the OECD is pushing to achieve. To illustrate this concern, an examination of implementation issues shows that the enactment of the income inclusion rule proposed in GloBE could paradoxically trigger the applicability of tax sparing clauses, even though both sets of regulations pursue opposing goals.

Tax sparing clauses have been assessed as an expression of the fiscal sovereignty of the jurisdictions demanding their adoption, mainly developing countries. Tax sparing provisions prevent residence states from taxing all or a portion of the income that remains untaxed at source. Tax sparing is a relevant expression of the jurisdiction not to tax of developing states and allows them to undertake policy decisions accordingly. Nonetheless, the approach to low or non-taxation through the adoption of tax incentives has changed significantly over recent years. The GloBE proposal, the latest development in this regard, aims at curbing tax competition at a comprehensive level by establishing a floor below which all cross-border income would be taxed at a minimum effective tax rate. Henceforth, the right of a jurisdiction not to tax as a form of expression of tax sovereignty is sacrificed to rebuild the ability of countries effectively to tax cross-border income. However, it remains unclear whether the proposal is the best option available for all parties concerned. Specifically, from the perspective of developing countries, the adoption of GloBE 
implies losing tax incentives as a tax policy instrument to attract foreign direct investment. This is why every country involved-but especially developing countries-should undertake a thorough examination to determine whether such measures are convenient for their interests in the long run.

In this respect, it is essential to emphasize that an adequate implementation of the measures proposed in Pillar Two is vital to achieve its declared policy goals. Most probably, the OECD will face an asymmetric scenario in which certain countries will indeed adopt the measures agreed upon, perhaps others will opt for a partial implementation, and others will plainly refuse them. The implementation of Pillar Two in domestic law, even if accompanied by measures to overcome incompatibility issues with tax treaties such as the saving clause, does not preclude the application of tax sparing clauses. Therefore, the implementation of the income inclusion rule of Pillar Two could paradoxically trigger the applicability of tax sparing clauses, even though their purported goals are mutually exclusive. This undesirable outcome could be solved by a proper agreement on the implementation of rules superseding tax sparing clauses by the parties involved through the adoption of measures that properly address these issues. A consent-based approach, perhaps enshrined in a multilateral instrument, would enhance legitimacy in the implementation of Pillar Two overall and would reduce the described normative frictions.

\section{References}

Altshuler, Rosanne and Harry Grubert. 2005. "The Three Parties in the Race to the Bottom: Host Governments, Home Governments and Multinational Companies." Florida Tax Review 7 (3): 153-84.

Arnold, Bryan. 2019. "The Evolution of Controlled Foreign Corporation Rules and Beyond." Bulletin for International Taxation 73 (12): 631-48.

Avi-Yonah, Reuven. 2000. "Globalization, Tax Competition, and the Fiscal Crisis of the Welfare State." Harvard Law Review 113 (7): 1573-676.

Beller, Charles. 2019. "GILTI: 'Made in America' for European Tax - Tax Unilateral Measures and Cooperative Surplus in the International Tax Competition Game." Virginia Tax Review 38 (3): 271-313.

Blum, Daniel. 2019. "The Proposal for a Global Minimum Tax: Comeback of Residence Taxation in the Digital Era?: Comment on Can GILTI + BEAT = GLOBE?" Intertax 47 (5): 514-22.

Blum, Daniel. 2018. "Controlled Foreign Companies: Selected Policy Issues - or the Missing Elements of BEPS Action 3 and the Anti-Tax Avoidance Directive." Intertax 46 (4): 296-312.

Brauner, Yariv. 2020. "Lost in Construction: What Is the Direction of the Work on the Taxation of the Digital Economy?" Intertax 48 (3): 270-2.
Brauner, Yariv. 2013. "The Future of Tax Incentives for Developing Countries." In Tax, Law and Development, edited by Yariv Brauner and Miranda Stewart, 25-56. Cheltenham: Edward Elgar Publishing.

Brooks, Kim. 2009. "Tax Sparing: A Needed Incentive for Foreign Investment in low-Income Countries or an Unnecessary Revenue Sacrifice?" Queen's Law Journal 34 (2): 505-64.

Canè, Daniele. 2017. "Controlled Foreign Corporations As Fiscally Transparent Entities." World Tax Journal 9 (4): 521-63.

Christians, Allison. 2016. "A Unified Approach to International Tax Consensus." Tax Notes International 96(6): 497-500.

Christians, Allison. 2016. "BEPS and the New International Tax Order." Brigham Young University Law Review (6): 1603-48.

Christians, Allison. 2013. "Putting the reign back in sovereign." Pepperdine Law Review 40 (special issue): 1373-414.

Dagan, Tsilly. 2000. "The Tax Treaties Myth." New York University Journal of International Law and Politics 32 (4): 939-96.

Devereux, Michael P., François Bares, Sarah Clifford, Judith Freedman, Irem Güçeri, Martin McCarthy, Martin Simmler and John Vella. 2020. "The OECD Global Anti-Base Erosion Proposal." Oxford University Centre for Business Taxation Working Papers, available at .

Diniz Magalhaes, Tarcisio. 2018. "What Is Really Wrong with Global Tax Governance and How to Properly Fix It." World Tax Journal 10 (4): 499-536.

Dourado, Ana Paula. 2020. "The Global Anti-Base Erosion Proposal (GloBE) in Pillar II." Intertax 48 (2): 152-6.

Englisch, Joachim and Johannes Becker. 2019. "International Effective Minimum Taxation - The GLOBE Proposal." World Tax Journal 11 (4): 623-80.

Faulhaber, Lilian. 2017. "The Trouble with Tax Competition: From Practice to Theory." Tax Law Review 71 (2): 311-66.

Gadžo, Stjepan and Šime Jozipović. 2020. "International Corporate Tax Regime Post-BEPS: A Regulatory Perspective." Intertax 48 (4): 432-45.

García Antón, Ricardo. 2019. "Multilateral Dynamics in Bilateral Settings: Back to Realpolitik." British Tax Review (4): 462-86.

Hattingh, Johann. 2020. "The Relevance of BEPS Materials for Tax Treaty Interpretation." Bulletin for International Taxation 74 (4/5): 179-96.

Herzfeld, Mindy. 2019. "The OECD Consults on a New Tax World Order." Tax Notes International 93: 468.

Hey, Johanna. 2021. "The 2020 Pillar Two Blueprint: What Can the GloBE Income Inclusion Rule Do That CFC Legislation Can't Do?" Intertax 49 (1): 7-13.

Hines Jr., James. 2000. "Tax Sparing and Direct Investment in Developing Countries." In International Taxation and Multinational Activity, edited by James Hines Jr., 39-72. Chicago: University of Chicago Press.

Kofler, Georg. 2016. "Some Reflections on the Saving Clause." Intertax 44 (8): 574-89.

Kuzniacki, Błazej. 2015. "The Need to Avoid Double Economic Taxation Triggered by CFC Rules under Tax Treaties, and the Way to Achieve It." Intertax 43 (2): 758-72.

Lang, Michael. 2003. "CFC regulations and double taxation treaties." Bulletin for International Fiscal Documentation 57 (2): 51-8.

Larking, Barry. 2020. "What the World Thinks of Pillar Two." Tax Notes International 98 (2): 185-204.

Li, Na. 2018. The Tax Sparing Mechanism and Foreign Direct Investment. Amsterdam: IBFD. 
Martín Jiménez, Adolfo. 2004. "The 2003 Revision of the OECD Commentaries on the Improper Use of Tax Treaties: A Case for the Declining Effect of the OECD Commentaries?" Bulletin for International Fiscal Documentation 58 (1): 17-30.

Martin, William. 1998. "Treaty Tax-Sparing Credits." Tax Management International Journal 27 (9): 444-65.

Mason, Ruth. 2020. "The Transformation of International Tax." American Journal of International Law 114 (3): 353-402.

Navarro, Aitor. 2020. "International Tax Soft Law Instruments: The Futility of the Static vs. Dynamic Interpretation Debate." Intertax 48 (10): 848-60.

Nogueira, João. 2020. "GloBE and EU Law: Assessing the Compatibility of the OECD's Pillar II Initiative on a Minimum Effective Tax Rate with EU Law and Implementing It within the Internal Market." World Tax Journal 12 (3).

OECD (Organisation for Economic Co-operation and Development). 1977. Income and Capital Model Convention and Commentary. Paris: OECD Publishing.

OECD. 1987. International Tax Avoidance and Evasion: Four Related Studies. Paris: OECD Publishing.

OECD. 1992. Income and Capital Model Convention and Commentary. Paris: OECD Publishing.

OECD. 1998a. Tax Sparing: A Reconsideration. Paris: OECD Publishing.

OECD. 1998b. Harmful Tax Competition: An Emerging Global Issue. Paris: OECD Publishing.

OECD. 1999. The Application of the OECD Model Tax Convention to Partnerships. Paris: OECD Publishing.

OECD. 2013a. BEPS Action Plan. Paris: OECD Publishing.

OECD. 2013b. Action Plan on Base Erosion and Profit Shifting. Paris: OECD Publishing.

OECD. 2015a. Designing Effective Controlled Foreign Company Rules: Action 3: 2015 Final Report. Paris: OECD Publishing.

OECD. 2015b. Countering Harmful Tax Practices More Effectively, Taking into Account Transparency and Substance: Action 5: 2015 Final Report. Paris: OECD Publishing.

OECD. 2015c. Preventing the Granting of Treaty Benefits in Inappropriate Circumstances: Action 6: 2015 Final Report. Paris: OECD Publishing.

OECD. 2015d. Transfer Pricing Documentation and Country-by-Country Reporting: Action 132015 Final Report. Paris: OECD Publishing.

OECD. 2015e. OECD/G20 Base Erosion and Profit Shifting Project: 2015 Final Reports: Executive Summaries. Paris: OECD Publishing.

OECD. 2017. Model Tax Convention on Income and on Capital: Condensed Version. Paris: OECD Publishing.

OECD. 2018. Tax Challenges Arising from Digitalisation - Interim Report 2018. Paris: OECD Publishing.

OECD. 2019a. Addressing the Tax Challenges of the Digitalisation of the Economy - Policy Note. Paris: OECD Publishing.

OECD. 2019b. Addressing the Tax Challenges of the Digitalisation of the Economy - Public consultation document. Paris: OECD Publishing.

OECD. 2019c. Programme of Work to Develop a Consensus Solution to the Tax Challenges Arising from the Digitalisation of the Economy. Paris: OECD Publishing.
OECD. 2019d. Global Anti-Base Erosion Proposal (“GloBE”) Pillar Two: Public Consultation Document. Paris: OECD Publishing.

OECD. 2020a. Statement by the OECD/G20 Inclusive Framework on BEPS on the Two-Pillar Approach to Address the Tax Challenges Arising from the Digitalisation of the Economy. Paris: OECD Publishing.

OECD. 2020b. Secretary-General Tax Report to G20 Finance Ministers and Central Bank Governors. Paris: OECD Publishing.

OECD. 2020c. Tax Challenges Arising from Digitalisation - Report on Pillar Two Blueprint. Paris: OECD Publishing.

Oguttu, Annet Wanyana. 2009. "Resolving the Conflict between 'Controlled Foreign Company' Legislation and Tax Treaties: A South African Perspective." The Comparative and International Law Journal of Southern Africa 42 (1): 73-114.

Parada, Leopoldo. 2021. "Full Taxation: The Single Tax Emperor's New Clothes." Florida Tax Review 24 (2021) (forthcoming).

Parada, Leopoldo. 2019. "The 'OECD Saving Clause': An AmericanTailored Provision Made to Measure the World." Rivista di Diritto Finanziario e Scienza delle Finanze, 78 (1): 13-52.

PCT. 2015. Options for Low Income Countries' Effective and Efficient Use of Tax Incentives for Investment, available at https://www.taxplatform.org/sites/pct/files/publications/100756-Taxincentives-Main-report-options-PUBLIC_0.pdf.

Ring, Diane. 2009. "Democracy, Sovereignty and Tax Competition: The Role of Tax Sovereignty in Shaping Tax Cooperation." Florida Tax Review 9 (5): 555-96.

Rocha, Sergio André. 2017. "The Other Side of BEPS: 'Imperial taxation' and 'International Tax Imperialism'." In Tax Sovereignty in the BEPS Era, edited by Sergio André Rocha and Allison Christians, 179-200. Alphen aan den Rijn: Kluwer Law International.

Rosenzweig, Adam. 2012. "Thinking Outside the (Tax) Treaty." Wisconsin Law Review (3): 717-786.

Rust, Alexander. 2008. "CFC Legislation and EC Law." Intertax 36 (11): 492-501.

Schoueri, Luís Eduardo. 2013. "Tax Sparing: A Reconsideration of the Reconsideration." In Tax, Law and Development, edited by Yariv Brauner and Miranda Stewart, 106-24. Cheltenham: Edward Elgar Publishing.

Rocha, Sergio André. 2014. "International Fiscal Imperialism and the 'Principle' of the Permanent Establishment." Bulletin for International Taxation 68 (2): 83-86.

Shannon, Harry. 1992. "Tax Incentives and Tax Sparing." Intertax 20 (2): 84-96.

United Nations. 2017. Model Double Taxation Convention between Developed and Developing Countries. New York: United Nations.

Wheeler, Joanna. 2012. The Missing Keystone of Income Tax Treaties. Amsterdam: IBFD. 